\title{
Sub-state nationalism and the welfare state: Québec and Canadian federalism
}

\author{
DANIEL BÉLAND* and ANDRÉ LECOURS*** \\ *Department of Sociology, University of Calgary, Alberta, Canada \\ **Department of Political Science, Concordia University, Montréal, Canada
}

\begin{abstract}
This article examines the relationship between sub-state nationalism and the welfare state through the case of Québec in Canada. It argues that social policy presents mobilisation and identity-building potential for sub-state nationalism, and that nationalist movements affect the structure of welfare states. Nationalism and the welfare state revolve around the notion of solidarity. Because they often involve transfers of money between citizens, social programmes raise the issue of the specific community whose members should exhibit social and economic solidarity. From this perspective, nationalist movements are likely to seek the congruence between the 'national community' (as conceptualised by their leaders) and the 'social community' (the community where redistributive mechanisms should operate). Moreover, the political discourse of social policy lends itself well to national identity-building because it is typically underpinned by collective values and principles. Finally, pressures stemming from sub-state nationalism tend to reshape the policy agenda at both the state and the substate level while favouring the asymmetrical decentralisation of the welfare state.
\end{abstract}

Nationalist movements in advanced industrial democracies operate in a political environment where decisions about a wide range of policy matters are taken on a regular basis. Overall, little attention has been paid to the relationship between nationalism and public policy as researchers have preferred to focus instead on the constitutional and institutional implications of claims for self-determination. To be fair, specialists of nationalism have not ignored all policy areas. There is a significant literature on nationalism and linguistic policies (McRae 1986; Laponce 2003). Education and broadcasting policies have also been studied for how they are affected by nationalist movements (Erk 2003). The interest in these particular policy areas is not surprising. After all, sub-state nationalism in Western Europe and Canada often features language as a key identity marker (for example, in Flanders, Catalonia and Québec), which means that language, education and broadcasting policies are likely to come under nationalist pressures. There has been much less research conducted on nationalism and policy fields not immediately related to language (or culture). ${ }^{1}$ This is perhaps because it is not readily expected that day-to-day policy-making in areas not featuring language (or culture) would shape nationalist movements, and that these movements would in turn affect policy-making in these areas. 
This article argues that social policy presents mobilisation and identitybuilding potential for sub-state nationalism, and that nationalist movements affect the structure of welfare states. Nationalism and the welfare state revolve around the notion of solidarity. Because they often involve transfers of money between citizens, social programmes raise the issue of the specific community whose members should exhibit social and economic solidarity. From this perspective, nationalist movements are likely to seek congruence between the 'national community' (as conceptualised by their leaders) and the 'social community' (the community where redistributive mechanisms should operate). Moreover, social policy lends itself well to national identity-building because it is typically underpinned by collective symbols and principles. Finally, welfare arrangements exposed to nationalist movements are likely to have different configurations than those that are not. More specifically, pressures stemming from sub-state nationalism tend to reshape the policy agenda at both the state and the sub-state level while favouring the asymmetrical decentralisation of the welfare state.

The article makes these arguments by examining the relationship between Québécois nationalism and social policy in Canada. Nationalism in Québec has been struggling, especially since the 1995 referendum, for the control of social policy and it has branded Québec's distinct social policies as further proof of the existence of a Québec nation, more progressive and egalitarian than the rest of Canada. The consequence of Québécois nationalism for the Canadian welfare state has been various patterns of asymmetry in the administration of social policy in the country. In some instances, however, asymmetry can lead to pressures for homogenisation across Canada through an agenda-setting dynamic. The existence in Québec of distinct social programmes puts pressure on the federal government and the government of the other provinces to adopt similar social provisions.

The article begins with theoretical considerations regarding the relationship between nationalism and social policy. It explains why social policy can act as a powerful force for nationalist mobilisation and nation-building and why the territorial structure of the welfare state is likely to be affected by nationalist pressures. We then consider the case of Québécois nationalism in Canada. We begin this empirical section with a brief discussion of the relationship between nationalism in Québec and the construction of the Canadian welfare state after 1940 as well as the changes brought to this dynamic by the Quiet Revolution and the rise of the Parti québécois (PQ). We then concentrate on the post-1995 referendum period to show how Québec political parties express the idea that different social policy preferences from the rest of Canada are at the centre of the province's national distinctiveness, and how Québec governments struggle with the federal government to preserve and increase its institutional autonomy over social policy matters. We also explain the consequences of these nationalist pressures for the Canadian welfare state. 


\section{Theoretical framework}

Nationalism is often described as the political expression of a special sense of solidarity among people. The sources of this solidarity are many. Scholars of nationalism have long insisted that belief in common descent is a powerful source of social unity (Smith 1999). A commonality of language facilitates social communication and may serve as the raw material for the construction of nations. Religion provides a set of common beliefs and practices, and the expectation of a common future may also be used to shape national communities (Hastings 1997). Modernists have argued that national solidarity was mostly generated by the state, more specifically by education systems, military conscription and service, and bureaucratisation for the purpose of resource extraction (Gellner 1983).

National solidarity also involves notions of equality and justice. The development of nationalism in Europe during the eighteenth and nineteenth centuries was concomitant with the rise of ideas like popular sovereignty and equality before the law (Kedourie 1993). As a result, nations are communities of equality insofar as their members are deemed to all have a similar status. From this perspective, nationalism triggers not only mechanisms of exclusion, which separate those who belong to the nation and those who do not, but also of inclusion. For members of the nation, there is also a promise of justice (Canovan 1996). In the words of David Brown: '[D]uring the twentieth century, nationalist elites have portrayed themselves as the agents of equitable development, so that the image of the nation has been reconstructed as the social justice community' (2000: 38). Inherent in this conceptualisation of the nation is the idea of a community united not only by shared memories, but also by the promise of a bright common future (ibid.).

Solidarity conceptualised in terms of equality and social justice ties nationalism to the welfare state. In the post-World War II period, advanced industrial societies, in the name of equality and social justice, developed new, comprehensive social programmes that served strong nation-building purposes. This effect was particularly important in multinational societies like the United Kingdom and Canada where there existed potential for centrifugal pressures on the nation articulated by the central state. In these countries, social citizenship stemming from welfare state development may have reinforced the sense of membership beyond existing regional and national differences (Brodie 2002; McEwen 2002).

For nationalist movements within these welfare states, the lack of congruence between their national community and the 'social justice' community can be problematic. The result is likely to be nationalist mobilisation for supporting claims to decentralise social policy or, in other words, to create a situation of 'indirect rule' with respect to the welfare state (Hechter 2000). In instances where there is a financial transfer from one group to the other, nationalist leaders can deplore the extension of social solidarity beyond national boundaries. This is the case in Belgium where Flemish parties seek 
the (partial) decentralisation of Social Security (Poirier and Vansteenkiste 2000). Even when there is no clear financial advantage to decentralise social policy, nationalist movements are likely to apply pressure on the central state. This was the case in Scotland during the 1990s as much of the devolution movement was premised on the idea that Scottish preferences about social policies were markedly different from those favoured by the Thatcher and Major conservative governments. In seeking control over social policy, nationalist movements can project powerful images about how their community is different from another because it espouses distinct values. For example, Scottish nationalism, much like Québécois nationalism, features the image of Scots as more egalitarian and progressive with respect to redistribution than the English (Keating 2005: 31). For sub-state nationalism, the control of social policy is much more than symbolic as social programmes like health and income support represent tangible manifestations of the political community (Miller 1995: 67-8) and are therefore potent tools for nation-building.

Sub-state nationalism can have a significant impact on social policy reform in advanced industrial societies. Overall, one can argue that sub-state nationalism may affect welfare state development in at least two ways: reshaping the policy agenda at both the state and sub-state levels, and reinforcing the push for policy decentralisation as an alternative to centralist schemes. Although these two phenomena are frequently related, it is useful to distinguish them analytically. First, as evidenced below, nationalist political actors can reshape the welfare agenda through the diffusion and implementation of specific policy alternatives. ${ }^{2}$ For example, nationalist forces in Flanders have pushed for a significant decentralisation of the welfare state as well as 'fairer' fiscal redistribution among regions. When nationalist parties gain power in a region, they may reshape the social policy agenda at the sub-state and, in some contexts, at the state level. Second, beyond the agenda-setting process, nationalist mobilisation favours the recognition of (or the increase in) substate policy autonomy. As a result, a likely outcome is to introduce asymmetry into the welfare state as regions with autonomous institutions where there exists a significant nationalist movement are granted partial control over social policy. This is the case of post-devolution United Kingdom with respect to Scotland (Keating 2005) and, as we discuss below, of Canada vis-à-vis Québec.

\section{Québécois nationalism and the welfare state}

The interaction between nationalism and welfare development in Canada appeared right from the early days of the modern welfare state. Starting during the World War II, the federal government developed a modern nationbuilding project where social policy was a crucial element. In 1940, Canada's House of Commons enacted federal unemployment insurance legislation that survived judicial review because of a constitutional amendment adopted with the support of the provinces. As the first federal social insurance programme 
ever adopted in Canada, unemployment insurance soon became a symbol of centralisation that extended beyond this particular policy area. In 1944, the enactment of a federal family allowance programme represented another major step towards welfare state centralisation as well as a direct intervention of the federal state in the everyday life of Canadian families. These developments were not welcomed by Québec's nationalist power structure featuring the Church and a conservative political elite represented primarily by the Union nationale party in power from 1944 to 1960 (Vaillancourt 1988). First of all, French-Canadian nationalism involved an opposition to state-run social programmes that could change the structure and political culture of society, which meant that the French-Canadian identity was defined against the ideology and values underpinning welfare development. Perhaps more importantly, the modern federal welfare state was also threatening the Church's position of power in Québec, which was sustained by its crucial role in delivering social services like health care and poor relief. Yet, despite its rhetoric against welfare centralisation, nationalism in Québec had few consequences for the Canadian welfare state in the 1940s and 1950s. In the context of a fundamentally defensive nationalism, the quest for insulation (rather than expansionist decentralisation) guided the provincial reaction to federal welfare state-building.

The relationship between nationalism in Québec and social policy changed significantly with the Quiet Revolution of the 1960s. At the centre of this modernisation project was the Québec government becoming involved in a struggle, rendered difficult by the long history of social conservatism, to improve the socio-economic position of Francophones. For the province's new liberal elite, this task involved assuming responsibility for the areas of education, health care and welfare at the expense of the Church, and struggling with the federal government for the decentralisation of social programmes. Québec governments claimed the right to 'opt-out' of federal programmes while obtaining financial compensation through a transfer of tax points. ${ }^{3}$ They were successful in many instances (hospital insurance, social assistance and vocational training), but in others (for example, unemployment insurance) the federal government resisted. What is noteworthy here is that the Québec government typically used this money to set up social programmes similar to the previously federal-administered ones (McRoberts 1993: 141), which highlights that symbolism was crucial. For Québec politicians, the development of autonomous provincial social programmes was a statement about the province's distinctiveness and its desire to take control of policy areas related to identity building. This initiative was perfectly coherent with the central claim of Québec's new nationalism that the province should have a special status within Canada because it bore the special responsibility of overseeing a Francophone majority.

In the 1970s, the connection between Québécois nationalism and social policy became tighter with the development of a social-democratic and secessionist party, the Parti québécois (PQ). The PQ's first political pro- 
grammes stressed the related objectives of the socio-economic advancement of Francophones and the reduction of socio-economic inequalities. Health care and income security were conceptualised as rights rather than needs (Parti québécois 1972: 41). After its surprise election in 1976, the PQ proceeded to enact several progressive policies: it raised the minimum wage to make it the highest in North America, introduced new income-maintenance programmes and adjusted taxation rates to benefit lower income earners (McRoberts 1993: 267). The PQ campaigned for 'sovereignty-association' in the 1980 referendum by presenting it as a means to emancipate Francophones and generate a more egalitarian society. The push for sovereignty was associated with socialdemocratic ideals, but discussions of specific social policies were avoided because they favoured the federalist side, which was arguing (with success) that sovereignty jeopardised Quebeckers' access to social benefits, most importantly pensions (Banting 1987).

The 1980s witnessed a change in the relationship between Québécois nationalism and social policy as references to the idea of social democracy became less central to nationalist discourse. This transformation was the product of a recession in the early 1980s, which meant that the second PQ government (1981-85), re-elected despite the referendum loss, stopped developing the types of progressive social policy that supported its claims of being a social-democratic party. Québec parties also enthusiastically supported free trade with the United States. Somewhat counter-intuitively, nationalism explains in large part support for free trade in Québec (Martin 1995), because it promised to position the province within a continental rather than a (Canadian) national economy. The link between Québécois nationalism and social policy also diminished in the 1980s and early 1990s because, at the time, territorial politics focused on constitutional negotiations.

The failure of these negotiations to produce a new constitutional amendment formally recognising a distinct status for Québec was a fantastic stimulant for the PQ, which interpreted the collapse of the Meech Lake and Charlottetown Accords as a rejection of Québec. The idea that independence could lead to the implementation of new progressive social policies was almost absent during the 1995 referendum on 'sovereignty-partnership' as were references to the (progressive) collective values of Quebeckers. ${ }^{4}$

In his concession speech, then Premier Jacques Parizeau blamed the defeat on 'money and the ethnic vote'. This targeting of Québec's cultural communities was widely criticised and the subsequent effort by the PQ to put this episode behind it and adopt an inclusive nationalist discourse was central to the re-articulation of nationalism and social policy.

\section{Social policy and Québécois identity}

The aftermath of the 1995 referendum presented a context full of paradoxes for the PQ government. The party was still devoted to Québec's independence, 
although secession was now unlikely in the short term. Language remained the central element of Québécois nationalism, but this emphasis, especially in the wake of Parizeau's comments, exposed sovereignist politicians to unwelcome charges of ethnic nationalism. Perhaps more importantly, Canada in the mid-1990s was undergoing a period of retrenchment featuring an unprecedented wave of neo-liberal reforms. As in most advanced industrial societies, the federal government had begun to fight large public deficits during the 1980s, a decade when market liberalism and fiscal retrenchment replaced Keynesianism and welfare expansionism. Although Canada did not face a radical and explicit neo-liberal crusade similar to the one launched by Margaret Thatcher and Ronald Reagan in the United Kingdom and the United States, free trade, economic competitiveness and the war on public deficits came to dominate Canada's policy agenda. In the field of social policy, the domination of neo-liberalism would materialise slowly, as governments attempted to implement cutbacks and pro-market reforms without alienating the electorate (Rice and Prince 2000). Not only was Québec poorly insulated from these developments, but it was greatly affected as financial transfers from the federal government slimmed down considerably. For the PQ, a selfdescribed social-democratic party whose ideological discourse was closely associated to its nationalist project, this context was particularly tricky. Not only was the PQ closely linked to progressive civil society networks featuring labour unions and feminist organisations, but the referendum defeat meant the end of a nationalist mobilisation pattern centred on the failures of constitutional negotiations that had served to place traditional, left versus right ideological issues in the background.

In the late 1990s, the PQ government responded to this difficult context by enacting several progressive social policies. Of foremost significance were the $\$ 5$ per-day daycare and universal drug insurance programmes. There were many motivations behind the creation of these programmes. Publicly funded daycare, for example, could be understood as a means to have women easily access the labour market and to increase Québec's low birth rates. However, the broader discourse around these programmes was about values and identity. In this context, social policy came back as a defining element of the Québécois identity. Despite the enactment of significant budget cutbacks by its government, the PQ has argued that Québec has a different cultural and political ethos from the rest of Canada, that it is more egalitarian and collectivist. Although many analysts would contest such claims, the PQ brands the daycare and drug insurance programmes, as well as other policies, as proof that Québec successfully resisted the neo-liberal turn taken elsewhere in Canada and in other advanced industrial countries. Another 'proof' of Québec's value and ideological distinctiveness was said to be the adoption by the PQ in December 2002 of an 'anti-poverty law' that formally committed the government to guarantee support for low income Quebeckers. Commenting on this policy, then Premier Bernard Landry said that the 'Québec model' was not only economic but about wealth redistribution (Lessard 2002). 
Alongside language, policies dealing with income support, child care and drug insurance have become an integral part of the nationalist discourse as they are said to both illustrate and reinforce the distinctiveness of the Québec nation. Sovereignist politicians argue that Québec is distinct from the rest of Canada not only because it is primarily French but also because it has its own set of social policies embedded in distinct values and priorities. For example, the 2000 PQ platform stated: '. . unitary Canada is developing following a vision different than ours, and its decisions stand in the way of our (social) project' (Parti québécois 2000: 160). In a 2005 policy statement, the Bloc québécois $(\mathrm{BQ})^{5}$ argues that when it comes to social matters, 'Québec is a creative society with high levels of solidarity' but warns that 'the measures that have allowed Québec to become the society in North America where wealth is most extensively redistributed are threatened' by the structures of Canadian federalism (Bloc québécois 2005: 10).

It is difficult to assess if there are indeed important differences between Quebeckers and other Canadians with respect to the importance given to values like equality of opportunity and general policy objectives like poverty reduction. Some surveys on 'social values' and policy choices show major differences ${ }^{6}$ while others do not. ${ }^{7}$ One topic that tends to produce a significant discrepancy is health care reform. Here, survey results contradict the Québécois nationalist discourse as they show that Quebeckers are much more likely than other Canadians to support involvement of the private sector in the health care system. ${ }^{8}$

The best demonstration of a close connection between the Québécois identity and progressive social policy is the reluctance of political actors to support explicitly neo-liberal reforms in this field, and the reaction of civil society organisations and movements when they do. An illustrative example here is the rise and fall of the Action démocratique du Québec (ADQ) in 200203. A small party created in the early 1990s as a splinter group from the PLQ (Parti libéral du Québec) over constitutional issues, the ADQ's popularity remained marginal until 2002 when it experienced a meteoric rise in opinion polls. A combination of factors explained this rise, including a strong autonomist (but not secessionist) stance, dissatisfaction with the PQ government and lukewarm support for Liberal leader Jean Charest. Somewhat hidden behind the personal popularity of its own leader, Mario Dumont, was the reason why the ADQ took fairly right-wing positions on many issues. For example, just before the 2003 provincial elections, the ADQ favoured policies, like school vouchers and a flat income tax, which stood in sharp opposition to the ideological profile of the Québec nation built over the last forty years. Sensing an opportunity, the PQ (and to a lesser degree the PLQ) zeroed in on the ADQ's policy platform, accusing the surging party of wanting to take Québec back forty years. The suggestion was clear: the ADQ's platform would destroy the building blocks of the modern Québec nation. Two things happened to the ADQ as it came under close scrutiny and heavy criticism. First, it backtracked on such things as vouchers and the flat tax, reducing 
them to 'interesting ideas' and 'long term objectives'. The ADQ also committed to keep Québec's daycare and drug insurance plan intact. Second, its popularity plummeted, which led to disappointing election results (18 per cent of the popular vote, compared to 33 per cent for the PQ and 46 per cent for the PLQ).

The story of the Québec Liberals under the leadership of Jean Charest also provides evidence of a significant connection between the idea of a Québec nation and progressive social policy. In the 1998 provincial electoral campaign Charest proclaimed the end of the Quiet Revolution and the beginning of a new era in Québec politics. This was widely viewed as a (neo-liberal) challenge to the 'Québec model'. Then PQ leader Lucien Bouchard replied by insinuating that Charest's ideas were foreign to Québec, linking them to the neoliberal policies of Ontario Premier Mike Harris. The PQ ended up soundly defeating the Liberals in these elections. References to welfare retrenchment and neo-liberal restructuring tend to be seen as attacks on Québec's nationhood, especially when they come from the PLQ whose nationalist credentials are often considered suspect.

In the 2003 provincial electoral campaign, the PLQ still ran promising change, but was careful to stress that changes would be congruent with 'our values and our national affirmation'. 'The ambitions of Quebeckers', the PLQ stated, 'are not those of our neighbours. We are different. We want to guide change. We want change that is coherent with us, and which unites us' (Parti libéral du Québec 2002: 5). With the ADQ now representing the 'radical' right-wing force and the PQ's popularity waning after nine straight years in government, the Liberals were able to form a majority government after running a quiet campaign. Once in power, the PLQ's 'discourse' of change became, or was perceived as, more explicitly neo-liberal. The PLQ focused its political mandate on the idea of 're-engineering' the Québec state, which was heavily criticised by most academics and intellectuals (Boismenu et al. 2004; Rouillard et al. 2004). From a broad comparative perspective with periods of welfare retrenchment in other jurisdictions, the PLQ's reforms have so far been fairly modest: labour legislation was amended to make sub-contracting easier; the original $\$ 5$ per day per child was increased to $\$ 7$ per day; and bursary funding for post-secondary students was reduced. The PQ denounced these reforms; this was predictable if only because of Québec's adversarialstyle democracy. More striking was the virulent reaction from civil society organisations: labour unions, anti-poverty, community and feminist groups as well as student associations staged significant demonstrations against the Liberal government and its policies. Of course, this opposition could be understood simply in ideological terms, but that would be missing the element making social policy reform so explosive: to undermine the welfare state is to undermine the national state. Because social policies have been erected as something that makes Québec different from the rest of Canada, there is a widely held belief that neo-liberal reforms would bring Québec 'down' to the level of just another province (Saint-Martin 2004). From this perspective, 
such reforms clash with the sense of distinctiveness underpinning sub-state nationalism. The notion of abandoning, or even tinkering with, the 'Québec model' is seen as a betrayal of the province's identity. Moreover, marginalising this distinctiveness is often said to be tantamount to weakening the province since claims for decentralisation in the social sphere are typically justified by the existence in Québec of different, more progressive, collectivist and egalitarian values. We now turn to this issue.

\section{Retrenchment, budget surpluses and nationalist mobilisation}

The immediate post-1995 referendum period in Canada corresponded to welfare retrenchment, although the shift from expansion to retrenchment started with the first mandate of the Mulroney government (1984-88). Thereafter, federal Conservative and Liberal governments used three main retrenchment strategies: benefit targeting, tightening of eligibility criteria and unilateral decentralisation (Baker 1997; Bashevkin 2000; Rice and Prince 2000). The first strategy concerned the incremental transformation of universal, citizenshipbased social programmes, like family allowances, into a targeted tax credit scheme. In the field of old age pensions, attempts to target basic benefits (Old Age Security) through the adoption of a tax device ('claw back') that takes them away from affluent citizens have proved far less successful (Béland and Myles 2005). Although criticised by the left in the name of universalism, this form of retrenchment did not trigger widespread provincial discontent because it focused on federal programmes rather than on fiscal transfers to the provinces. Stricter eligibility criteria, the second retrenchment strategy, mainly affected the federal unemployment insurance programme, whose name was changed to Employment Insurance in order to symbolise the logic of 'activation' that encouraged the unemployed to return to the labour market as soon as possible. Retrenchment in unemployment insurance proved unpopular in Québec but the most radical forms of discontent surfaced in the poorer Maritimes provinces (Rice and Prince 2000). Like tighter eligibility criteria, unilateral decentralisation, the third retrenchment strategy, became dominant during the first mandate of the Liberal government (1993-97). This form of retrenchment proved a major stimulant to Québécois nationalism. Unilateral decentralisation refers to massive reduction in the federal funding of provincial programmes through the creation of predetermined 'block grants' replacing traditional matching funds. The adoption of the Canada Health and Social Transfer in 1996 illustrates the logic of unilateral decentralisation at work in the mid-1990s. Instead of equally sharing the costs of assistance programmes between the federal and provincial government, this legislation implemented a block grant strategy aimed at controlling - and lowering - federal social assistance spending. To reduce the potential level of provincial discontent, the Liberal government combined unilateral retrenchment with a normative deregulation of social assistance. As a consequence, the provinces gained 
almost full autonomy in the management of their social assistance programmes (Boychuk 1998).

In Québec, welfare retrenchment at the federal level offered new opportunities and new arguments for nationalist mobilisation. For the PQ, the new fiscal constraints placed upon Québec by the federal government's cuts in financial transfers to the provinces endangered the ability of the Québec government to promote social development. The three years of post-referendum retrenchment opened the way for a nationalist discourse denouncing Canadian federalism for depriving Québec of the financial resources needed to develop and preserve progressive social programmes, that is, policies coherent with the values and preferences of Quebeckers. Throughout 1998, then Premier Lucien Bouchard criticised the federal government for being unresponsive to Québec's social needs, preferring instead to spend on the printing of Canadian flags on checks, buildings and advertising. ${ }^{9}$ He also denounced Prime Minister Jean Chrétien for putting money towards debt reduction saying that for the federal government: 'Ottawa's debt is important. But Ottawa's debt towards patients, Jean Chrétien does not care. Ottawa's debt towards the unemployed, victims of the reform, Jean Chrétien does not care. ${ }^{10}$ For Bouchard and the PQ, federal retrenchment was an argument for independence: the federal government was using Quebeckers' money for priorities like debt reduction instead of making it available for social needs. Yet at the same time, the PQ government was seeking to eliminate the province's own deficit, and presenting this exercise as laying the foundations for sovereignty. ${ }^{11}$

As the federal government began to register significant budget surpluses beginning in the late 1990s, the nationalist discourse became more straightforward: the bulk of the financial resources needed to support Québec's progressive social programmes were in Ottawa. Québec politicians have called this discrepancy between federal revenues and the level of provincial spending required to sustain existing programmes the 'fiscal imbalance'. From a broader comparative perspective, this is an issue common to most federations as federal governments tend to have greater taxation powers while federated units are empowered to act in areas that are expensive to fund (i.e. health and education). In Québec, there is a consensus among the three parties represented in the provincial parliament (PQ, PLQ, ADQ) that fiscal imbalance is a problem that needs to be addressed. The federal Liberal government sees no problematic imbalance, suggesting that if Québec wants to generate more income it should simply raise its taxes.

The PQ has used the refusal of the federal government to correct this imbalance to portray it as a centralising and domineering force threatening Québec's distinctively progressive social policies. It argues that the only political choice left for Quebeckers who wish to preserve their social programmes, and therefore their identity, is sovereignty. 'Only Québec sovereignty will give us full control over our social development. Promoting greater equality, encouraging more meaningful participation and favouring a global approach to problems means that only one government, ours, should 
formulate policies' (Parti québécois 2000: 160). Short of independence, the PQ opposes the federal government's presence in social policy fields where it considers the Québec government to have exclusive jurisdiction. In some cases, like labour training or maternity leave, it has sought the decentralisation of programmes (successfully in the former, unsuccessfully in the latter). In other cases, like health care, it has sought to increase federal funding while keeping the federal government away from intervening in the programme's management. Any such attempt on the part of the federal government becomes a rallying cry for nationalist politics. For example, when the report of a federal commission ('Romanow Commission') mandated to investigate the future of health care in Canada came out in November 2002 with recommendations to increase 'targeted funding' (i.e. where the federal government would define priorities and make financial transfers conditional upon spending in specified areas) and to create a federal monitoring body, the PQ reacted with vitriol. The commission's report was called a 'takeover' of Québec's health care system and a 'frontal attack against Québec's identity' (Hanes 2002; Séguin 2002). PQ leaders stated that they would prefer to abandon the money rather than comply with federal conditions and threatened to hold a referendum on health care financing (Hanes 2002). The nation-building properties of the health care system in Canada were nicely illustrated by commissioner Romanow's plea to the Prime Minister to 'get tough with premiers who demand more health-care money without conditions' because 'Canada's medical system and national identity' depended on it (Smith 2002).

The connection between sovereignty and progressive social policy is strong. Of course, not all sovereignists are left-leaning and supportive of far-reaching and highly redistributive social policies. Some PQ politicians embrace neoliberalism but they operate within disciplined parties whose majority supports greater state interventionism, which means their views on sovereignty are seldom heard. Similarly, not everybody self-identifying as a social democrat (or socialist) supports sovereignty, or makes it a priority. An interesting debate in this respect is occurring at the margin of Québec's party system where a new party, Option citoyenne, spearheaded by feminist activists, is tackling 'the great taboo of the national question' by disentangling sovereignty and socialism and prioritising the latter (Conradi et al. 2004). Published replies to this approach stated that one would have to be 'blind' not to see that the most progressive elements in Québec were sovereignists (Beaudry and Comeau 2004). Critics point to Québec's social programmes, 'the most advanced in Canada', to argue that any alliance with forces from elsewhere in the country to change politics in Canada as a whole would be fruitless. They also argue that an ambitious social democratic programme cannot fully materialise with Québec as a Canadian province.

For the PLQ as it took power in 2003, tackling the issue of fiscal imbalance involved both maintaining a feisty attitude towards the federal government and generating new momentum and institutions for inter-governmental relations. At a discursive level, it is very important for the PLQ to be critical 
of the federal government in order to be able to present itself as a firm defender of Québec. For example, reacting to Ottawa's proposal for a compassionate leave programme, the PLQ complained about another 'intrusion' into Québec's jurisdiction. Nationalist leaders also blame the federal government for provincial fiscal problems and for unpopular cutbacks enacted in the province. PLQ (as well as PQ) governments have long argued, for example, that the province's health care system suffers from Ottawa's under-funding.

In addition to maintaining a belligerent attitude towards the federal government since coming to power in 2003, the PLQ has sought to devise new mechanisms of inter-governmental relations to pressure the federal government into more funding for province-run social programmes like health insurance. In this context, Québec's Liberal government spearheaded the creation of a Council of the Federation to serve as a forum where provincial governments could co-ordinate their positions and build up stronger leverage in their relations with Ottawa.

Strikingly, the role of social policy in nationalist mobilisation in Québec is often unrelated to the specifics of a programme. Québec governments rarely seek to decentralise social programmes because they want to do something radically different from the federal government; this was true during the Quiet Revolution and it still holds today. In some instances, the specific features of programmes would be tweaked; for example, the Québec government has said that it would like to administer maternity leave to extend the period of coverage by a few weeks. But most importantly, decentralist claims about social policy should be understood within a particular institutional dynamic. Canadian federalism features provincial governments with substantial autonomy as well as distinct and well-regarded political classes (Théret 2002). ${ }^{12}$ As a result of the mutation of the essentially defensive French-Canadian nationalism into a more proactive Québécois nationalism in the 1960s, there developed a tremendous political will to promote and protect Québec's distinctiveness and policy autonomy. As we saw, social policy featured prominently in this equation, and the province's political elite could use the legitimacy and constitutionally recognised jurisdictions of their institutions to struggle for decentralisation in this field. At the other end of that struggle is a federal government that also appreciates the value of social programmes for national cohesion (Brodie 2002), and that has made strategic decisions about whether or not to transfer competence in specific policy areas to Québec or to make a special arrangement with the province. From this perspective, federalism not only provides a structural dynamic for the social policy/ Québécois nationalism nexus to play out, but is also on its receiving end.

\section{The impact of nationalist mobilisation on social policy}

Québécois nationalism has stimulated asymmetry in social policy in Canada. This asymmetry comes from the province's social policy innovations (for 
example, child care) but also from nationalist pressures on the central administration of many social programmes. From this perspective, we can distinguish several different patterns.

A first pattern is when a power historically exercised by the federal government is decentralised to Québec but not to the other provinces. This type of asymmetrical decentralisation, when it occurs, always constitutes a response to nationalist pressures in Québec. Typically, the federal government formally states that it is open to broaden the decentralisation to other provinces, although it knows that only one wants to assume new responsibilities. Obviously, not all Québec claims for decentralisation are met with this response from the federal government, which is also keen to retain meaningful links with Quebeckers. For example, Ottawa has been fighting off demands from the Québec government to run its own maternity leave programme. In the case of labour training, however, the federal government decided to respond positively to Québec's decentralist claims as, in the aftermath of a close referendum result, there was immense pressure on the federal government to show flexibility and demonstrate the possibilities for accommodation within Canadian federalism.

The earliest and perhaps most significant instance of asymmetrical decentralisation in the field of social policy was pensions. In the mid-1960s, political pressures from Québécois nationalism favoured the enactment of distinct but co-ordinated earnings-related public pension programmes: the Québec Pension Plan (QPP) and the Canada Pension Plan (CPP), which covers workers in the nine other provinces. The levels of the payroll tax and replacement rate are identical for both schemes. Because the federal and provincial governments share constitutional responsibility for this programme, Ottawa must reach an agreement with at least two-thirds of the provinces representing two-thirds of the Canadian population before enacting a reform. Furthermore, the need for policy co-ordination within the Canadian pension system means that Québec must be consulted before any reform of the Canada Pension Plan is enacted (Béland and Myles 2005).

A second pattern of asymmetry when it comes to social policy is what has been called 'federalism with a footnote' (Noël 2000). Consensus over social policy reform or new initiatives is hard to attain in Canadian federalism because provinces are usually looking to protect their own autonomy to act. Yet, most of the time, provincial governments other than Québec can be persuaded to accept joint social programmes or policy co-ordination with the federal government. For Québec governments, however, autonomy in crafting and administering social programmes is a priority. With the PQ in power during the late 1990s, the political strategy became to simply disengage from federal-provincial discussions about social policy in Canada. As a consequence, agreements for new policy initiatives like the National Children's Agenda came with a footnote stipulating that the Québec government, although supporting the principle behind the proposal, did not wish to participate. 
Provincial mobilisation to reform federal-provincial relations in the field of social policy led to the emergence of the Social Union Framework Agreement (SUFA). At first, SUFA constituted a genuine effort to stop unilateral, discretionary federal retrenchment that proved so detrimental to provinces. By August 1998, even the PQ government had formally joined the interprovincial coalition over this issue. Yet, in the end, Québec opted out of the final agreement, and the final version of SUFA adopted by Ottawa and nine of the ten provinces in 1999 did not really restore confidence and 'collaboration' in the Canadian federal system. For political scientist Alain Noël, this final agreement only exacerbated the recent concentration of power in Canadian federalism:

Collaborative federalism is hierarchical. In fact, Canadian federalism has never been more centralised. Power is concentrated not only in Ottawa, but also at the top, in the prime minister's 'court.' Collaboration occurs, but it is the collaboration of rowing agents who follow the indications of a steering principal whose behaviour is difficult to understand, let alone to predict. ... Collaboration, of course, also takes place without Québec, the only government that would challenge federal hegemony in a fundamental way (Noël 2000: 11).

Pointing to Québec's grievances regarding the final agreement, this quote underlines the clear link between SUFA and the debate on 'national unity'. According to the PQ's 2000 platform, SUFA 'allows the federal government to usurp Québec's power over education, health, the family, and social security/welfare. The Social Union takes our social policies hostage and therefore directly threatens our social development' (Parti québécois 2000: 160). From this perspective, SUFA constituted a threat to Québec's interests, not a solution to enduring federal-provincial tensions.

Another pattern of asymmetry with respect to the implementation of social policy in Canada has come recently in the form of a distinct agreement between the federal and Québec governments over health care funding. The agreement requires nine provinces to comply with measures of accountability regarding the delivery of health care services while exempting Québec. Similarly, it sets for these nine provinces specific priorities (for example, expanding home-care services), which do not bind the Québec government. As such, this agreement on health may create a new pattern in Canadian federalism where Québécois nationalism triggers an asymmetry not so much linked to a decentralisation of power to the province, but rather to an uneven configuration in the way policy objectives are set and outcomes monitored. Many observers saw in this deal a precedent for the future exercise of policy co-ordination in Canada that would include separate arrangements with Québec. Indeed, the concept of 'asymmetrical federalism', said to allow 'for the existence of specific agreements for any province', was featured for the first time in a formal text (Thompson 2004). As such, the health accord may structure Canadian federalism above and beyond the social policy domain. For example, a few days after having signed the accord, Québec Premier Jean 
Charest announced that he was seeking the formalisation of the province's role in international affairs through a similar agreement with Ottawa.

Nationalism in Québec has impacted the development of social programmes within Canadian federalism not only by forcing asymmetry, but also by framing the terms of political debate in the social policy domain (and beyond). In other words, Québécois nationalism has been a substantial agenda-setting force in Canada. For example, the theme of 'fiscal imbalance' was taken up by the other provinces. After the PQ government organised, in 2001, a Commission sur le déséquilibre fiscal (Commission on Fiscal Imbalance), the disparity in resources between Ottawa and Québec City was identified by all the Québec parties as a major problem. When the PLQ took power in 2003, it successfully promoted this theme with the other provinces to pressure the federal government more effectively to increase funding for social programmes. Although the federal government formally denied the existence of a fiscal imbalance, it increased funding for health care (the major loser of the fiscal imbalance according to Québec parties) when faced with a united front of provinces.

A final pattern of agenda-setting by Québécois nationalism in Canada stems from the tangible influence exerted by social policies enacted in Québec in the name of the province's distinctiveness. For example, Québec's childcare programme has put pressure on the federal government to create a similar (Canadian) national policy. In discussion about childcare reform across the country, experts have referred to the 'Québec model' as one of the main policy options available to policy-makers at the federal level as well as in other provinces (Tougas 2001). In the 2004 federal election campaign, the Liberal party alluded to child care à la québécoise when promising new policy in this area. In their government's first budget, the Liberal party pledged no less than five billion dollars over five years to set up a national childcare framework. Of course, Québec is not the only province to have played a central role in social policy mimesis and learning processes across the country (Jenson 2001). Yet, Québec's distinctive social policies and its political importance within the Canadian federation make it a crucial player in the field of social policy reform in Canada. Innovative policies enacted in the province are often referred to as good examples to follow by left-leaning politicians in other parts of the country. This influence of Québec's social policies elsewhere in Canada is rather paradoxical insofar as the province's politicians and social actors have associated them with Québec's own national identity and distinctiveness.

\section{Conclusion}

This article has shown how nationalism in Québec involves social policy as part of its identity-building and mobilisation processes. The connection between the Québécois identity and preferences for progressive social policy emerged in the 1960s and 1970s as sub-state nationalism became focused on 
the socio-economic advancement of Francophones through state intervention. By the late 1990s, specific social policies were said to exemplify the distinctiveness of a Québec society deemed more progressive, egalitarian and compassionate than the rest of Canada. These notions of distinctiveness then shaped patterns of nationalist mobilisation geared towards the asymmetrical decentralisation of social policy and, in the case of the PQ, arguments for independence on the grounds of fundamental differences about the nature of society and the role of the state as translated in welfare arrangements. Of course, one could credibly argue that social policy preferences in Québec and elsewhere in Canada are fairly close. But this is beside the point: Québec's nationalist politicians and interest groups made up of labour unions and other left-leaning organisations that are tightly embedded in the 'Québec state' maintain the existence of two societies with different values.

Future research about the relationship between sub-state nationalism and social policy could take a more comparative perspective. As in Canada, social policy is a focal point of nationalist mobilisation in Belgium and the United Kingdom (Béland and Lecours 2005). In Belgium, most Flemish parties seek the partial or full 'federalisation' (i.e. decentralisation) of social security. For Flemish nationalists, the financial transfers from Flanders to Wallonia implicit in the mechanisms of social security are intolerable because they amount to a redistribution beyond their community of reference (Poirier and Vansteenkiste 2000). In the United Kingdom, the Scottish drive towards home rule in the late 1980s and the 1990s was strongly centred around the idea that Scotland should be able to craft and implement social policy. In the context of the Thatcher years, Scottish nationalism (conceptualised in the broadest sense, that is, beyond the Scottish National Party) developed a discourse suggesting that Scots were more collectivist and egalitarian than the English, and that they therefore needed autonomy to devise social policy according to these distinct values. This dynamic makes the connection between nationalism and social policy in Scotland similar to the one that exists in Québec. The result of this mobilisation pattern in Scotland was devolution, which led to some social policy divergence between Scotland and England (McEwen 2002). For example, the Scottish Executive developed a personal long-term care programme for the elderly and adopted a different approach to health care and social exclusion (Keating 2005). In Belgium, by contrast, Flemish mobilisation around social policy has triggered little change in the territorial management of social security as the participation in the management of social security of social partners that have not split upon linguistic lines (labour unions and business organisations) and consociational practices between Flemish and Francophones parties (the latter strongly opposes federalisation) represent structural conditions favouring inertia.

Finally, at the theoretical level, it would be important to analyse the role of institutional, ideological and economic factors in mediating the connection between nationalism and the welfare state. The most general message of this article is that students of nationalism should pay greater attention to social 
policy as a site of identity-formation and nationalist mobilisation, both at the state and the sub-state level. It is to be hoped that more empirical work will enrich the rather limited literature on the relationship between national identity and social policy.

\section{Notes}

1 For an exception, see McEwen 2001, 2002.

2 On the concept of agenda, see Kingdon 1995.

3 This is when 'the federal government reduced its tax rates in the province and the provincial government simultaneously raised its taxes by the same amount'. See Banting 1995: 286, note 25.

4 There is evidence that the PQ made this type of argument to their labour and feminist movement partners to keep them mobilised. For example, feminist leader Françoise David has stated being told that a 'yes' vote was necessary to prevent 'a right-wing wind coming from Ontario' to touch Québec. See Hachey 2005.

5 The BQ is the PQ's sovereignist counterpart at the federal level.

6 For example, in a survey conducted in 2002, 68 per cent of Quebeckers thought it was the government's responsibility to reduce the gap between rich and poor compared to 42 per cent in the rest of Canada. See http://www.cric.ca/pdf/cahiers/cahierscric_com_dec2002.pdf.

7 For such an inconclusive survey, see http://www.cric.ca/pdf/cric_poll/portraits/por traits1998_comm.PDF. Among the results, 'equality of chances' was said to be very important by 68 per cent of Quebeckers compared to 78 per cent of Canadians outside Québec, while 77 per cent of Quebeckers compared to 76 per cent of Canadians living outside Québec considered that it was very important to act on the issue of 'reduction of poverty'.

8 For example, in 200249 per cent of Quebeckers were willing to allow the private sector to provide health care services versus only 33 per cent of Canadians living outside Québec. See http:// www.cric.ca/pdf/cric_poll/portraits/portraits_2002/portraits02_sante.pdf.

9 See a speech delivered to the PQ's national council on 21 February 1998 at http:// www.premier.gouv.qc.ca/general/discourse/archives_discours/1998fevrier/dis1998/fevrier/ dis $19980221 . h t m$, p. 3.

10 See a speech delivered to the PQ's national council in September 1998 at www.premier. gouv.qc.ca/general/discours/archives_discours/1998/septembre/dis19980918.htm, p. 3.

11 See the two speeches cited above.

12 By this we mean that provincial politicians are not considered 'second-class' politicians in comparison to their federal counterparts.

\section{References}

Baker, Maureen. 1997. 'The Restructuring of the Canadian Welfare State', Social Policy Research Centre Discussion Paper No. 77. Sidney.

Banting, Keith. 1987. The Welfare State and Canadian Federalism. Kingston: McGill-Queen's University Press.

Banting, Keith. 1995. 'The welfare state as statecraft: territorial politics and Canadian social policy' in Stephan Leibfried and Paul Pierson (eds.), European Social Policy: Between Fragmentation and Integration. Washington, DC: The Brookings Institution, 269-300.

Bashevkin, Sylvia. 2000. 'Rethinking retrenchment: North American social policy during the early Clinton and Chrétien years', Canadian Journal of Political Science 33(1): 7-36.

Beaudry, Lucille and Robert Comeau. 2004. 'Quand le social occulte la question nationale', Le Devoir 14 July. 
Béland, Daniel and André Lecours. 2005. 'The politics of territorial solidarity. sub-state nationalism and social policy reform in Canada, the United Kingdom, and Belgium', Comparative Political Studies 38: 676-703.

Béland, Daniel and John Myles. 2005. 'Stasis amidst change: Canadian pension reform in an age of retrenchment' in Giuliano Bonoli and Toshimitsu Shinkawa (eds.), Ageing and Pension Reform around the World. Cheltenham: Edward Elgar, 252-72.

Bloc québécois. 2005. Imaginer le Québec souverain, proposition principale.

Boismenu, Gérard, Pascale Dufour and Denis Saint-Martin. 2004. Ambitions libérales et écueils politiques. Réalisations et promesses du gouvernement Charest. Outremont: Athéna.

Boychuk, Gerard W. 1998. Patchworks of Purpose: the Development of Provincial Social Assistance Regimes in Canada. Kingston: McGill-Queen's University Press.

Brodie, Janine. 2002. 'Citizenship and solidarity: reflections on the Canadian way', Citizenship Studies 6: 377-94.

Brown, David. 2000. Contemporary Nationalism: Civic, Ethnocultural and Multicultural Politics. London: Routledge.

Canovan, Margaret. 1996. Nationhood and Political Theory. Cheltenham: Edward Elgar.

Conradi, Alexa and Françoise David and François Saillant. 2004. 'Le grand tabou de la question nationale', Le Devoir 24 July.

Erk, Jan. 2003. "Wat we zelf doen, doen we beter"; Belgian substate nationalisms, congruence and public policy', Journal of Public Policy 23: 201-24.

Gellner, Ernest. 1983. Nations and Nationalism. Oxford: Blackwell.

Hachey, Isabelle. 2005. 'Ringards, les souverainistes? Réinventer l'échiquier politique', La Presse 6 February.

Hanes, Allison. 2002. 'We'll refuse the money if necessary: Québec', The Gazette 29 November.

Hastings, Adrian. 1997. The Construction of Nationhood: Ethnicity, Religion and Nationalism. Cambridge: Cambridge University Press.

Hechter, Michael. 2000. Containing Nationalism. Oxford: Oxford University Press.

Jenson, Jane. 2001. 'Family policy, child care and social solidarity: the case of Québec' in Susan Prentice (ed.), Changing Child Care: Five Decades of Child Care Advocacy and Policy in Canada. Halifax: Fernwood Publishing, 39-62.

Keating, Michael. 2005. The Government of Scotland: Public Policy Making after Devolution. Edinburgh: Edinburgh University Press.

Kedourie, Elie. 1993. Nationalism (4th edn). Oxford: Blackwell.

Kingdon, John W. 1995. Agendas, Alternatives and Public Policy (2nd edn). New York: HarperCollins.

Laponce, Jean. 2003. 'Canada: the case for ethnolinguistic federalism in a multilingual society' in John Coakley (ed.), The Territorial Management of Ethnic Conflict (2nd edn). London: Frank Cass, 23-45.

Lessard, D. 2002. 'Québec dépose un projet de loi antipauvreté', La Presse 8 June: A1-A2.

McEwen, Nicola. 2001. 'The nation-building role of state welfare in the United Kingdom and Canada' in Trevor C. Salmon and Michael Keating (eds.), The Dynamics of Decentralization: Canadian Federalism and British Devolution. Kingston: McGill-Queen's University Press, $85-105$.

McEwen, Nicola. 2002. 'State welfare nationalism: the territorial impact of welfare state development in Scotland', Regional and Federal Studies 12: 66-90.

McRae, Kenneth D. 1986. Conflict and Compromise in Multilingual Societies: Belgium. Waterloo, Ont.: Wilfrid Laurier University Press.

McRoberts, Kenneth. 1993. Québec: Social Change and Political Crisis. Toronto: McClelland \& Stewart.

Martin, Pierre. 1995. 'When nationalism meets continentalism: the politics of free trade in Québec', Regional and Federal Studies 5: 1-27.

Miller, David. 1995. On Nationality. Oxford: Clarendon Press. 
Noël, Alain. 2000. Without Québec: Collaborative Federalism with a Footnote. Montreal: IRPP Working Paper, 1, 2, March, 5.

Parti libéral du Québec. 2002. Un gouvernement au service des Québécois. Ensemble, réinventons le Québec.

Parti québécois. 1972. Prochaine étape... Quand nous serons vraiment chez nous.

Parti québécois. 2000. Programme du parti québécois.

Poirier, Johanne and Steven Vansteenkiste. 2000. 'Le débat sur la fédéralisation de la sécurité sociale en Belgique: le miroir du vouloir-vivre ensemble?', Revue belge de sécurité sociale 2: 331-79.

Rice, James J. and Michael J. Prince. 2000. Changing Politics of Canadian Social Policy. Toronto: University of Toronto Press.

Rouillard, Christian, Éric Montpetit, Isabelle Fortier and Alain-G. Gagnon. 2004. La Réingénérie de l'État: vers un appauvrissement de la gouvernance québécoise. Québec: Presses de l'Université Laval.

Saint-Martin, Denis. 2004. 'La réforme de l'État-providence: l'État social québécois n'a pas été producteur que de corporatismes mais aussi d'identité', La Presse 8 January.

Séguin, Rhéal. 2002. 'Romanow call for greater control may lead to spring vote', Globe \& Mail 30 November.

Smith, Anthony D. 1999. Myths and Memories of the Nation. Oxford: Oxford University Press. Smith, Graeme. 2002. 'Romanow warns PM: Don't cave in', Globe \& Mail 2 December.

Théret, Bruno. 2002. Protection sociale et fédéralisme: l'Europe dans le miroir de l'Amérique du nord. Montréal: Presses de l'Université de Montréal.

Thompson, Elizabeth. 2004. 'Québec deal a first', The Gazette 17 September: A1.

Tougas, Jocelyne. 2001. Childcare in Québec: Where There's a Will, There's a Way. Child Care Advocacy Association of Canada.

Vaillancourt, Yves. 1988. L'Évolution des politiques sociales au Québec, 1940-1960. Montréal: Presses de l'Université de Montréal. 